\title{
Towards a new politics of migration?
}

\section{$\underline{\text { Abstract }}$}

This paper reconsiders Stephen Castle's classic paper Why Migration Policies Fail. Beginning with the so-called 'migration crisis' of 2015 it considers the role of numbers is assessing success or failure. It argues that in the UK public debates about immigration changed with EU Enlargement in 2004, when the emphasis shifted from concerns about asylum to concerns about EU mobility. Concerns were exacerbated by the government's failure to meet its promise to reduce net migration. This policy is hampered by the general problem of definition of 'migrant' and the gap between statistical measures and popular usage in which 'migration' signifies problematic mobility. In fact, concern about migration has become a placeholder for concerns about globalisation and democratic accountability. A new politics of migration must make connections between migrants and citizens, but also between migration and other global processes, particularly outsourcing and the exploitation of labour and resources in the global south

Key words: Stephen Castles, migration, "refugee crisis", Brexit, EU enlargement, globalisation

The UNHCR estimates that more than one million people entered Europe by sea in 2015. At least 3,700 drowned. The vast majority of entrants were from refugee producing countries, and the top three countries of origin were Syria, Iraq, and Afghanistan, all countries where United States and European foreign policy is deeply implicated in war and instability. Nearly one half of entrants were from Syria, most coming via Turkey to Greece. As the situation in Syria had become even more unstable and the possibility of return looked ever more remote, a proportion of the 2.5 million Syrians in Turkey began to look towards building a future rather than tolerating a present and moved towards Europe. Like the apocryphal story that the Haitian slave revolutionaries greeted the repressive French army by singing the Marseillaise, so some of the people walking along the motorways of Hungary and Austria were carrying the European flag. 'We share your respect for justice, freedom and human rights and here we are! We belong!' The European Union response has been widely characterised as a failure. Borders began to be erected between different EU member states. States to the East of Europe were accused of racism, states to the North of hypocrisy. Even proposals whose effect would be principally symbolic foundered. In September 2015 EU member states had committed to relocating 160,000 refugees in order to relieve the pressure on the edges of Europe, particularly Greece. Recognising the desperate situation facing Syrians in particular it was also agreed to resettle 22,500 people from camps. These extremely modest targets proved too much: by July 2016 relocations from Greece and Italy numbered only 3,056 and less than half the resettlement target had been reached.

Given the contemporary context the analysis laid out in Stephen Castle's classic 2004 ERS article Why Migration Policies Fail is highly prescient. In this boldly titled paper he argues that policies largely fail to prevent 'unwanted flows' and to manage immigration and integration effectively (though the emphasis of the paper is largely on the former). He finds three reasons for this failure: factors arising from the social dynamics of the migratory process, including social networks, the migration industry, migrant agency, and families and life stage; factors linked to globalization, transnationalism and the North-South divide; and political factors within sending and receiving states, including conflicts of interest, structural dependence, welfare states and civil society pressures. The paper then examines European Union attempts to address 'root causes' of migration 
through conflict prevention and measures to improve economic conditions in sending countries. He finds that these have been half-hearted, and in practice efforts have been directed not towards these structural factors but rather enforcement and the prevention of 'illegal migration'. The paper concludes by arguing that migration must be recognised as a social process with its own inherent dynamics and that contemporary migration is an integral feature of globalization and North-South relations. Problematic mechanisms of policy formation and the restrictions imposed by electoral cycles must be countered by 'joined up policy-making'. 'Migration control is really about regulating North-South relationships and maintaining inequality. Only when the central objective shifts to one of reducing inequality will migration control become both successful and - eventually - superfluous' (Castles, 2004: 224). In summary: migration policies fail because they are about migration.

Such failure has significant human consequences. On $31^{\text {st }}$ July 2016 the body of a Syrian refugee, Wisan Sankari, was found in Istanbul, raped, tortured and decapitated. He had been desperately trying to leave Turkey because of the hostility and violence he faced as a gay man. This is the price of policy failure. However, while for the EU and its member states the problem is migration, for people on the move, the problem is the border guard, not migration per se. That is, arguably Wisan is one of those who have paid the price of policy success. In late 2015 the EU trebled spending on border 'defence' and announced the establishment of a European border and Coast Guard. In March 2016, Macedonia, Croatia and Slovenia closed the 'Balkans route', making it impossible for people arriving in Greece to reach Northern Europe. A few days later, the European Commission struck a deal that provided the framework for the mass return of migrants from Greece to Turkey. This was agreed despite multiple concerns including claims from Amnesty International that Turkey was conducting illegal mass returns of Syrians to Syria on a daily basis (Amnesty International 2016). Numbers entering Greece, though still significant, dropped dramatically. Ways out of Turkey for young men in particular, were closed.

Success or failure depends, as Castles recognises, on its measurement. While migration policies are failing if one measures success in terms of respect for human rights, migration policies are succeeding in diverting significant public resources to the private purse. Vast amounts of state money are poured into mobility controls, technology and policing of borders, the maintenance and expansion of the detention estate, and the funding of in-country enforcement, checks and raids. Much of this money is paid to private companies: in 2015 the security firm G4S was the largest publicly-traded employer in Europe, and the second largest world-wide. In a move, not simply paralleling, but intertwined with the prison system, the profit extracted through the exploitation of predominantly but not only negatively racialized bodies, is being superseded by the profit gained from the management and control of those bodies. The 'migration industry' identified by Castles as a factor explaining policy failure, not only comprises the 'travel agents, lawyers, bankers, labour recruiters, brokers interpreters and housing agents' but today includes private security agencies and powerful financial actors (Andrijasevic 2015).

For those involved in the migration industry, in general the more bodies processed the better, but for policy makers and politicians the ostensible goal is reduced numbers. As with criminals, governments are always open to the charge that there are 'too many' migrants and 'too many' is a difficult number. One million entrants to the European Union were "too many" but it was less than $0.5 \%$ of the EU population. At the other end of the scale, one migrant murderer not deported is always one too many. The shared interest between migration industry players and politicians might 
appear to be robust enforcement. However, high numbers of border refusals and removals do not necessarily reduce public anxiety about immigration. They may even compound it by serving as proof that there is a serious problem of too many people wanting to enter the country, or entering illegally, and that the extent of that problem is yet to be uncovered.

Mainstream commentators and 'pro-migrant' NGOs have typically responded by arguing that fears about large numbers entering a country are unfounded, that when people are free to come and go and not illegalised, they are often less likely to stay and that the poorest people in the world do not have the means to move very far. That is, there has been a tendency to claim that 'not a lot of people will come' rather than challenging the logic of numbers in the first place. However, in recent years, people attempting to enter Europe have indeed been using sheer numbers to overwhelm border posts. Whether running at the fences of Melilla, pulling down the barricades at Macedonia, jumping on to the trains and ferries at Calais, or hiding in the ranks of hundreds of no borders activists walking across frontiers, the weight of numbers is being transformed into a means of resistance. Crowds are breaking down fences and mass co-ordinated crossings are proving difficult to halt. As a border guard interviewed at Melilla put it: 'we can stop them when they come two at a time, but if there are 2,000 at each point, we cannot' (Gall 2014). This is the very antithesis of 'managed migration', the careful identification, points systems and processing of migrants that lies at the heart of migration and refugee policy. It invokes old fears of the mob (quite literally, the mobile) at the same time as contrasting the democratic people and the labouring class with the dangerous and disorganised masses.

In the UK fear of numbers contributed to the pro-Brexit vote in the 2016 referendum on EU membership. In fact the beginning of concerns about EU mobility dates from around the date of the publication of this paper. Until then the main focus for public anxiety was the numbers of 'bogus asylum seekers'. In May 2004 the EU expanded from fifteen (EU15) to twenty five ('Accession 8' plus Cyprus and Malta) member states. All EU15 states except for the UK, Ireland and Sweden restricted access to their labour markets for A8 nationals for seven years by invoking transitional measures. The dominance of English language and the UK's deregulated labour market meant that there were already significant numbers of A8 nationals residing in the UK even before EU Enlargement, working as self-employed construction workers, au pairs and in hospitality. A reading of Castles' paper might have anticipated significant EU mobility to the UK. However, academic advisers had predicated preenlargement that not imposing transitional measures would result in an inflow of some 12,000 A8 nationals a year (Dustmann et al. 2003). In the event there were approximately 50,000 new entrants a quarter until the 2008 crash. Migration is notoriously difficult to forecast (Disney et al 2015) and this massive discrepancy was in part because of the unexpected imposition of transitional measures by other EU states, but it haunted the Labour administration, and changed the focus of the British immigration debate. Until then there had been little interest in mobility from the European Union. The movement of German au pairs and Spanish waiters was not of particular concern, but post 2004 claims that low waged EU 'migrants' were taking British jobs, moved to the tabloid centre stage.

The incoming 2010 Coalition government attempted to deal with the problem of numbers head on by adopting a 'net migration' policy which aimed to achieve a balance of 'migrants in' minus 'migrants out' within the tens of thousands. This has exposed an additional problem with migration policy, fixated as it is on numbers: who counts as a migrant is not clear. Headlines about foreigners 'taking' a disproportionate share of jobs proliferate. But the data come from the Office of National 
Statistics, and the definition used is 'foreign born': a person may be 'foreign born' and nevertheless be a British citizen by naturalization, or be a British citizen born abroad, by being the child of a parent serving in the British armed forces for example. Prince Philip is 'foreign born' but rarely is he considered a 'migrant'. The net migration policy itself does not use 'foreign born' as a definition of migrant, but the UN definition of Long Term International Migrant, i.e. 'A person who moves to a country other than that of his or her usual residence for a period of at least a year... so that the country of destination effectively becomes his or her new country of usual residence'. That is, the policy is using a different definition than that assumed by the politics of national press, but notably in both the citizenship of the person is not relevant. Under the net migration policy, a British young person who has been working in Japan for a few years and is now coming home, counts as an incoming migrant, while a British couple leaving to spend their retirement in Spain are outgoing migrants.

Not all of those who are counted as 'migrants' in the net migration policy can have their mobility controlled through immigration policy: UK citizens, long term residents, EU nationals and asylum seekers are not subject to the levers of immigration controls. Indeed, there have been longstanding objections to defining EU mobility as an immigration issue at all. When Austria, Britain, Germany and the Netherlands wrote in a joint letter to the Irish presidency and the Commission, to complain that "certain immigrants from other member states [...] avail themselves of the opportunities that freedom of movement provides, without, however, fulfilling the requirements for exercising this right" the then Home Affairs Commissioner Cecilia Malmström's response strongly objected to their use of the word 'immigrant'. "EU citizens who have the right to travel, live, work and study where ever they want in the Union are put on a par with immigrants from countries outside the EU. For instance, they are being called EU immigrants, a concept that does not exist". Viviane Reding, then Commissioner for Justice, Fundamental Rights and Citizenship supported this stance: "Let language not betray us: European citizens exercising their right to free movement are not 'immigrants'. All European citizens have the same rights." (Cited in Hansen 2015)

'Migration' signifies problematic mobility. People have always moved, and human movement is only contingently constituted as an object of investigation and a problem for policy. Not all mobility is subject to scrutiny, but 'migration' already signals the need for control and in public discourse is often raced and classed. In liberal democracies the laws governing migration manage the mobility of the poor tangentially through nationality and citizenship and the language of skill, education and the brightest and the best. Bacchi (2009) has argued that social policies do not simply respond to an already existing problem, but are often critical to the production of the phenomenon as a 'problem' in the first place. Migration laws and policies do not only 'manage migration' but, are critical to the production of social and employment relations. Importantly, immigration controls are not simply about conditions of entry but about conditions of stay. Once non-citizens have entered legally they are subject to particular conditions depending on their visa status. For example, in most countries the majority of non-citizens who are admitted to work have their access to the labour market limited in some way. Those entering as economic migrants can work for a recognized sponsor only, and are effectively on fixed term contracts that may be terminated at the employer's discretion. Immigration controls are not simply taps that attempt (successfully or not) to control the flows of entry of noncitizens, but they are moulds, that shape social relations. In this way, workers who are subject to immigration controls may be more desirable to employers than those who are not. Far from protecting citizen low waged labour, in certain sectors immigration requirements can actually create 
employment relations that make migrant workers preferable to citizen workers. What is bad for migrants is not necessarily good for citizens, and regulations that work to marginalise and exclude migrants, do not necessarily centralise and include citizens.

A government's perceived failure to control immigration can be seized on for electoral purposes, but it also must be seen within a broader political context. The context of the contemporary obsession with migration, reducing numbers and right wing populism, is a nation state form in crisis. Often imagined as reaching into the mists of European history, the global expansion of the nation state system is relatively recent, dating from the last 60 years. While there has been considerable academic critique of the analytic utililty of concepts like 'the state' and 'the market' which comprise the traditional tools of liberal politics and sociology, as well as significant shifts in ways of thinking about power, nevertheless the state/government continues to be the frame through which public discourse understands the distribution and accountability of political and economic power (Rose 1999). It is a frame that is proving increasingly shaky. Borders have fallen, shifted, and proved vulnerable while global capital, finance and new technology are proving highly resistant to state regulation (Brown 2010). This is exacerbated by a crisis in representation, as political elites are felt to be ever more removed from the lives of the majority of the population. These crises of the nation state and representation are intertwined, and for some the European Union has become representative of both. Promises of strong control over immigration appeal to the hope of a national labour market and economy, a stable cohesive national society and representative democratic politics. The migrant exemplifies the fluidity of relations between nation, people, and state. Their presence becomes emblematic of the nation as beholden to business, human rights and European interests as well of mainstream politicians' disengagement with everyday problems. This was one of the factors influencing the pro-Brexit vote as multiple political anxieties coalesced around migration. That is, this should not be analysed simply as a policy failure that permitted 'too many' migrants to enter the UK, but the consequence of multiple policies that disenfranchised and impoverished millions of people on the one hand, and years of setting up 'migrants' as the reason for lack of jobs, low wages, poor public services and so on. This unleashes powerful politics on the street and in the ballot box. It was not the migration policy failure that lay behind Brexit, but the long term political success of scapegoating migrants.

At the same time, the response to migration must be analysed in a context in which, from the European point of view, the lives of those from outside Euro-America are disposable (Klein 2016). Lives are becoming increasingly unsustainable. This was put thus by then UK Foreign Secretary, Phil Hammond:

The gap in standards of living between Europe and Africa means there will always be millions of Africans with the economic motivation to try to get to Europe...So long as there are large numbers of pretty desperate migrants marauding around the area, there always will be a threat to the tunnel security. We've got to resolve this problem ultimately by being able to return those who are not entitled to claim asylum back to their countries of origin... Europe can't protect itself, preserve its standard of living and social infrastructure if it has to absorb millions of migrants from Africa.

'Marauding' might be a better description of European racism, slavery and imperialism in Africa, and Asia. This marauding offered benefits, not only to the wealthy capitalists and the middle classes, but 
also to British citizens more generally. Richard Drayton, Rhodes Professor of Imperial History at Kings College London writes: "When in about 1950 British democracy created a welfare state at home, it too depended on invisible donations from tea-pickers in Ceylon, rubber-tappers in Malaya, goldminers in South Africa, copper-miners in Rhodesia, the oil of Iraq and especially Iran" (Drayton 2012: 162). The reliance of the national welfare state on the profit derived from workers abroad suggests we must think twice before complaining about non-citizens taking advantage of the National Health Service.

The reliance of European standards of living on the exploitation of labour in the Global South is not only historical. There has in recent years been a massive shift in production from North to South. John Smith has demonstrated that developing countries' share of global manufactured exports was around $5 \%$ in the 1950 s to $30 \%$ by the year 2000 , to currently some $60 \%$. The proportion of the industrial workforce living in less developed regions was 79\% in 2010, up from 34\% in 1950 (Smith 2015). Goods are affordable for impoverished workers (and non-workers) in the Global North because of a system of resource extraction, outsourcing and arms length super exploitation in the Global South. States' alleged concerns to protect low waged labour markets for its workers (high waged labour, interestingly, merits no such protection) are not matched by controls on outsourcing, and there is no possibility for self-sufficiency in an era of dependence on fossil fuels and rare metals.

Anti-migrant politics disavow these connections, seeing only foreigners in search of the good life and jobs. This politics has been analysed by some as effectively a means of dividing the national working class from non-citizen workers, thereby weakening both, as nationals see, not fellow workers, but foreigners who 'take jobs' and undermine conditions. Less attention has been paid to the ways in which the migrant as a subordinated subject divides differently racialized groups. These divisions are not new. The complaints from 'old' immigrants about new arrivals are well documented, both within the same national groups who can complain that new arrivals are spoiling it for them, and between different nationalities within the same group - seizing on their relative advantage: Syrians complaining about Afghans, or Filipinas complaining about Indians. It may also be racialized - Polish complaining about Asian bosses. Of course there is also solidarity, and camaraderie, but the residue of hostility can be mobilised for political purposes as was apparent in the EU referendum debate. The migration 'problem' is no longer identified as migrants from the Global South but those from 'eastern Europe'. Nigel Farage, leader of UKIP and one of the key 'vote leave' voices, claimed that leaving the EU would mean 'more black people would qualify to come in'(Dathan 2016) Writing in the Daily Telegraph he explained 'UKIP wants to ensure that highly skilled people from the Commonwealth - from India, Canada, New Zealand and beyond ${ }^{1}$ - get a fair chance to get into Britain, unlike now, where we give precedence, via our open border with the European Union, to half a billion people from Europe and its former Communist countries' (Farage 2015). This is an effective appeal to Empire over Europe, and, via 'highly skilled' and through the inclusion of India, class over race. It builds on a longstanding argument: it is not racist to be concerned about immigration because migrants are from Eastern Europe, migrants are white, Black British people don't like Eastern Europeans, and Black people are not racist - but also Eastern Europeans are racist. The figure of the migrant places a complex and often contradictory role in racialisation processes: simultaneously evidence of tolerance and threatening tolerance, a new political subject and a threat

\footnotetext{
${ }^{1}$ This prompts the question: what is 'beyond' New Zealand' if one's starting point is the UK?
} 
to the polis, shaping ideas of shared identity by incorporation and rejection, but inevitably raising the question of incorporation/rejection into/from what?

From one perspective migration policies fail because the subject of the migrant is partially created by law and policy, but also endlessly eludes it. 'The migrant' is often a placeholder, marking memories of empire, or fears of globalisation, or a sense of impending catastrophe. This has consequences for academic research. If the 'migrant' is a constructed figure, made by policy and public discourse, and the separation of 'migration' from other areas of policy is one of the causes of the problem, what does this mean for academic research which reifies the migrant subject? How can we scholars, who are also part of the 'migration industry' conduct work on migration? The identification of a population and associated problems draws even those researchers who strive for analytical objectivity into participation in politics and governance (Bacchi 2009). This is particularly challenging in fields such as ours, where funding and institutional regimes privileging 'impact' and 'stakeholder engagement' mean there is a risk that the field of enquiry is apt to be disproportionately shaped by policy agendas. Problematizing the problem of migration is a reflexive moment in which to examine the fraught relation between the academic and the political that is exposed in the critical study of the social. To develop the potential of migration scholarship requires us to move beyond empirical (and occasionally empiricist) inflections and situate social scientific investigations within a continuous reflection on how and why mobility is made an object of discourse and policy, and what kind of knowledge is produced as migration is rationalized, analysed and classified, that is to transform the problematization of migration into a tool for inquiry.

One way into doing this is by engaging with the instability of 'the migrant' insofaras it exposes the instability of who counts as a citizen, and indeed of citizenship itself. There has been little work to date on what these troubling disruptions to the imagining of political rights entail for those who are formal citizens, but they are of considerable consequence. This is evident in a banal way in the ways in which legal citizens become migrants in data, and in disputes such as those over whether EU citizens are 'migrants' or 'mobile citizens'. There are also ways in which the negativity associated with 'migrant' can be turned against citizens. For example, the UK's 2011 Localism Act has meant that English Local Authorities have competence over the allocation of social housing, an extremely scarce resource and in the past few years they have produced Social Housing Allocation policies. These commonly denounce migrants for all the usual problems: increased housing pressure, crime, drugs and so on. However, often, "By migration we are not just talking about people moving to and from the UK, it also means the movement of people to and from different parts of the country" (Tendring District Council 2016), that is, British citizens on welfare benefits can also be classified as 'migrants'. Moreover, the policy response to these migrants is remarkably similar to naturalisation requirements, limiting access to social resources through a length of stay requirement (in some places up to ten years before a person can get on the housing waiting list) and through behavioural requirements.

As observed at the beginning of this piece, promises of strong control over immigration appeal to the hope of a national labour market and economy, a stable cohesive national society and representative democratic politics. These hopes are understandable, but they will not be attained by exerting ever tighter control over immigration. Indeed, the risk is that the obsession engendered by immigration only increases exploitation in labour markets, destabilises neighbourly relations and 
caricatures democratic politics. The contemporary challenge is to draw out the connections between increasing European poverty and associated popular anger and resentment on the one hand, and the deaths and desperation battering at Europe's borders on the other. This is at the moment reduced to a simple message: "'we' must look after our own first. We must first attend to the housing, benefit and health needs of the British/European population. Sorry but there is not enough to go around." How to build connections between the low waged, homeless and unemployed EU citizens, those struggling to get by, and the struggles of migrants without turning them into competitors for the privileges of membership? How to jump the scales and the borders of the local, national and global and make the connections between them? There are important connections to be made between migrants and citizens, but the analysis can't be abstracted from political and social practice. It can offer clues that must be followed and developed through campaigning and organising and people's daily experiences of building relationships with one another. We are in for the long haul of building an economy, culture and society where better lives for Syrians, Eritreans, Afghans and Pakistanis, mean better lives for everyone.

\section{$\underline{\text { References }}$}

Amnesty International (2016) 'Illegal mass returns of Syrian refugees expose fatal flaws in EU-Turkey deal'. Available from https://www.amnesty.org/en/latest/news/2016/04/turkey-illegal-massreturns-of-syrian-refugees-expose-fatal-flaws-in-eu-turkey-deal/ last accessed $6^{\text {th }}$ September 2016

Andrijasevic, R. (2015) 'The commercialization of Migration Control' in Anderson, B. and Shutes, I. Citizenship and Its Others, pp. 89-93 Basingstoke: Palgrave Macmillan

Bacchi, C. (2009) Analysing Policy: What is the problem represented to be? Pearson

Brown, W. (2010) Walled States, Waning Sovereignty New York: Zone Books

Castles, S. (2004) 'Why Migration Policies Fail’ Ethnic and Racial Studies 27(2) 205-227

Drayton, R. (2012) 'Imperial History and the Human Future' History Workshop Journal 74: 156-172

Dustmann, C., Casanova, M., Fertig, M., Preston, I.P. and Schmidt, C.M. (2003) The Impact of EU Enlargement on Migration Flows. London, Home Office Report 25/03.

Gall, C. (2014) 'At a Spanish Border, a Co-ordinated Scramble' New York Times $23^{\text {rd }}$ July. Available from http://www.nytimes.com/2014/07/24/world/europe/migrants-say-storming-of-spanishborder-fences-is-carefully-coordinated.html? $r=0$ last accessed $6^{\text {th }}$ September 2016

Dathan, N. (2016) 'More black people will be allowed into Britain if we leave the EU and immigration will become a 'non-issue', says Nigel Farage' The Daily Mail $8^{\text {th }}$ June Available from http://www.dailymail.co.uk/news/article-3630847/More-black-people-allowed-Britain-leaveEU-immigration-non-issue-says-Nigel-Farage.html\#ixzz4JTFbw18B last accessed $6^{\text {th }}$ September 2016

Disney, G., Wiśniowski, A., Forster, J.J, Smith, P.W.F., and Bijak, J. (2015) Evaluation of existing migration forecasting methods and models. Report for the Migration Advisory Committee. Southampton: University of Southampton. Available from 
https://www.gov.uk/government/uploads/system/uploads/attachment data/file/467405/Migration Forecasting report.pdf last accessed 6th September 2016

Dustmann, C., Casanova, M., Fertig, M., Preston, I.P. and Schmidt, C.M. (2003) The Impact of EU Enlargement on Migration Flows. London, Home Office Report 25/03.

Farage, N. (2015) 'UKIP's Immigration Policy is Built on Fairness' The Daily Telegraph $3^{\text {rd }}$ March Available from http://www.telegraph.co.uk/news/politics/nigel-farage/11447132/Nigel-FarageUkips-immigration-policy-is-built-on-fairness.html last accessed 6th September 2016

Gall, C. (2014) 'At a Spanish Border, a Co-ordinated Scramble' New York Times $23^{\text {rd }}$ July. Available from http://www.nytimes.com/2014/07/24/world/europe/migrants-say-storming-of-spanishborder-fences-is-carefully-coordinated.html? $r=0$ last accessed $6^{\text {th }}$ September 2016

Hansen, P. (2015) 'Undermining Free movement: migration in an age of austerity' Eurozine $2^{\text {nd }}$ June . Available from http://www.eurozine.com/articles/2015-02-06-hansenp-en.html last accessed 6th September 2016

Klein, N. (2016) 'Let Them Drown: the violence of othering in a warming world' London Review of Books $2^{\text {nd }}$ June.

Rose, N. (1999) Powers of Freedom: reframing political thought. Cambridge: Cambridge University Press

Smith, J. (2015) 'Imperialism in the Twenty-First Century' Monthly Review 67(3) available from http://monthlyreview.org/2015/07/01/imperialism-in-the-twenty-first-century/ last accessed $6^{\text {th }}$ September 2016 